\title{
PENGARUH STRATEGI PEMBELAJARAN KOOPERATIF NUMBERED HEAD TOGETHER DENGAN STUDENT TEAMS ACHIEVEMENT DIVISION DAN KECERDASAN GANDA TERHADAP HASIL BELAJAR IPS
}

\author{
Maulina Siregar, Abdul Hasan Saragih, Julaga Situmorang \\ Sekolah Menengah Kejuruan Negeri 1 Meranti, Sumatera Utara \\ Maulina_riregar@gmail.com
}

\begin{abstract}
Abstrak: Penelitian ini bertujuan untuk mengetahui: (1) hasil belajar kelompok siswa yang diajar dengan menggunakan strategi pembelajaran NHT lebih tinggi daripada siswa yang diajar dengan menggunakan strategi pembelajaran STAD; (2) kelompok siswa yang memiliki kecerdasan interpersonal memperoleh hasil belajar IPS lebih tinggi dibandingkan dengan kelompok siswa yang memiliki kecerdasan intrapersonal; dan (3) interaksi antara strategi pembelajaran NHT dan strategi pembelajaran STAD dan kecerdasan ganda (kecerdasan intrapersonal dan kecerdasan interpersonal) terhadap hasil belajar IPS. Metode yang digunakan dalam penelitian ini adalah metode penelitian eksperimen semu (quasi eksperiment). Hasil penelitian menunjukkan: (1) hasil belajar IPS siswa yang diajar dengan menggunakan strategi pembelajaran NHT (rata-rata 81,95) lebih tinggi dibandingkan hasil belajar siswa yang diajarkan dengan strategi pembelajaran STAD (rata-rata 79,10); (2) hasil belajar IPS siswa yang memiliki kecerdasan interpersonal (rata-rata 84,06) lebih tinggi dibandingkan kelompok siswa yang memiliki kecerdasan intrapersonal (ratarata 77,64); dan (3) terdapat interaksi antara strategi pembelajaran dan kecerdasan ganda tehadap hasil belajar IPS siswa.
\end{abstract}

Kata Kunci: strategi pembelajaran NHT, STAD, kecerdasan ganda, IPS

Abstract: This study aims to determine: (1) the learning outcomes of groups of students taught using NHT learning strategies are higher than students taught by using STAD learning strategies; (2) groups of students who have interpersonal intelligence get higher social studies learning outcomes compared to groups of students who have intrapersonal intelligence; and (3) the interaction between NHT learning strategies and STAD learning strategies and multiple intelligences (intrapersonal intelligence and interpersonal intelligence) on social studies learning outcomes. The method used in this research is quasi-experimental research method. The results showed: (1) Social studies learning outcomes of students who were taught using the NHT learning strategy (an average of 81.95) were higher than the learning outcomes of students taught with the STAD learning strategy (an average of 79.10); (2) social studies learning outcomes of students who have interpersonal intelligence (on average 84.06) higher than groups of students who have intrapersonal intelligence (on average 77.64); and (3) there is an interaction between learning strategies and multiple intelligences towards students' social studies learning outcomes.

Keywords: NHT learning strategies, STAD, multiple intelligence, social studies

\section{PENDAHULUAN}

Pada hakikatnya belajar adalah proses perubahan tingkah laku individu yang penekanannya ditujukan pada siswa. Menurut konstruktivistik belajar juga diartikan sebagai suatu proses pembentukan pengetahuan dimana siswa diharapkan mampu membangun atau merekonstruksi pengetahuannya melalui aktivitas pembelajaran yang dilakukan. Dalam teori humanistik, belajar adalah proses memanusiakan manusia, maksudnya proses dianggap berhasil apabila siswa memahami lingkungan dan dirinya sendiri (Budiningsih, 2008). Dengan kata lain belajar juga dapat diartikan sebagai proses mental dan fisik melalui interaksi antar siswa, siswa dengan guru, lingkungan dan sumber belajar dalam rangka mencapai kompetensi. Proses ini dikatakan berhasil apa bila siswa yang terlibat dalam proses tersebut mampu mencapai kompetensi yang diharapkan.

Sebagaimana yang dikemukan Gagne bahwa terdapat tiga fungsi guru dalam mengajar yaitu: sebagai perancang dalam pembelajaran, 
pengelola pembelajaran dan sebagai evaluator pembelajaran (Hamid, 2009). Oleh karena itu sebagai desainer (perancang) guru harus memiliki kompetensi untuk melakukan pemilihan startegi pembelajaran yang disesuaikan dengan karakter siswa dan materi ajar yang pada akhirnya membuat suatu pembelajaran yang unik dan menarik. Adapun yang menjadi dasar pemilihan strategi dalam proses pembelajaran adalah: (1) Mengidentifikasi serta menetapkan spesifikasi dan kualifikasi perubahan tingkahlaku dan kepribadian anak didik sebagaimana yang diharapkan. (2) Memilih sistem pendekatan belajar mengajar berdasarkan aspirasi dan pandangan hidup masyarakat. (3) Memilih dan menetapkan prosedur, metode dan teknik belajar mengajar yang dianggap paling tepat dan efektif sehingga dapat dijadikan pegangan oleh guru dalam melaksanakan kegiatan mengajarnya. (4) Menetapkan norma-norma dan batas minimal keberhasilan atau kriteria serta standart keberhasilan sehingga dapat dijadikan pedoman oleh guru dalam melakukan evaluasi hasil kegiatan belajar mengajar yang selanjutnya akan dijadikan umpan balik buat penyempurnaan sistem intruksional yang bersangkutan secara keseluruhan. (Djamarah dan Zain, 2010)

Lebih detail Sanjaya (2010) mengemukakan bahwa terdapat 7 peran guru yaitu: (1) Guru sebagai sumber belajar (pengusaan guru terhadap materi ajar) (2) Guru sebagai fasilitator (memberikan pelayanan untuk memudahkan siswa dalam kegiatan proses pembelajaran) (3) Sebagai pengelola (menciptakan iklim belajar yang membuat siswa merasa nyaman) (4) Sebagai demonstrator (mempertunjukkan kepada siswa segala sesuatu yang membuat mereka paham dan mengerti setiap pesan yang disampaikan (5) Sebagai pembimbing (membimbing siswa untuk menumbuh kembangkan potensi, minat dan bakatnya) (6) Sebagai motivator (mendorong siswa untuk lebih giat belajar) (7) Sebagai evaluator (mengumpulkan data atau informasi tentang keberhasilan pembelajaran yang telah dilakukan.

Berbagai strategi pembelajaran telah ditawarkan oleh para ahli guna mengatasi masalah-masalah pembelajaran. Menurut Miarso (2007) strategi pembelajaran merupakan pendekatan menyeluruh pembelajaran dalam suatu sistem pembelajaran, yang berupa pedoman umum dan kerangka kegiatan untuk mencapai tujuan umum pembelajaran yang dijabarkan dari pandangan falsafah atau teori belajar tertentu. Diantaranya strategi pembelajaran adalah Numbered Head Together (NHT) dan Student Teams Achievement Division (STAD). Menurut Trianto (2011) NHT atau penomoran berpikir bersama merupakan tipe dari pembelajaran kooperatif yang dirancang untuk mempengaruhi pola interaksi siswa dan sebagai alternatif terhadap struktur kelas tradisional. Sedangkan STAD adalah model pembelajaran kooperatif dengan menggunakan kelompok-kelompok kecil dengan jumlah anggota tiap kelompok 4-5 orang siswa secara heterogen. Di awali dengan penyampaian tujuan pembelajaran, penyampaian materi, kegiatan kelompok, kuis dan penghargaan kelompok.

Kedua strategi pembelajaran tersebut merupakan tipe dari model pembelajaran kooperatif di mana guru hanya berperan sebagai fasilitator dan motivator dalam proses pembelajaran sehingga siswa mampu mencapai tujuan dari kompetensi yang diharapkan. Lebih lanjut Slavin (dalam Solihatin dan Raharjo, 2009) menyatakan bahwa cooperative learning adalah suatu model pembelajaran di mana siswa belajar dan bekerja dalam kelompok-kelompok kecil secara kolaboratif yang anggotanya terdiri dari 4-6 orang, dengan struktur kelompok yang bersifat heterogen.

Kondisi ini semakin diperparah dengan adanya anggapan bahwa pembelajaran IPS adalah pengetahuan yang dapat ditransfer secara utuh dari guru kepada siswa, sehingga siswa hanya dituntut untuk menghafal konsepkonsep yang sudah ada. Hal ini dipertegas oleh pendapat Arends (dalam Trianto, 2011) yang menyatakan bahwa di dalam mengajar guru selalu menuntut siswa belajar dan jarang memberikan pelajaran tentang bagaimana siswa untuk belajar, guru juga menuntut siswa untuk menyelesaikan masalah, tapi jarang mengajarkan siswa bagaimana cara menyelesaikan masalah. Hal tersebut didukung oleh pendapat Sanjaya (2010) yang menyatakan bahwa dalam proses pembelajaran anak kurang didorong untuk mengembangkan kemampuan berpikir. Pernyataan ini mengadung makna bahwa selama ini siswa hanya dijejali oleh pemahaman konsep yang ditunjukan dengan hasil belajar yang tinggi akan tetapi guru tidak memperhatikan pemaknaan dari konsep yang ditunjukkan dari sikap dan perilaku siswa dalam kehidupan sosialnya. 
Indikasi lain juga menunjukkan bahwa proses pembelajaran yang monoton dan kurangnya variasi, hal ini sering disebut teacher centered (berpusat pada guru) yang menyebabkan siswa bosan dan malas mengikuti proses tersebut. Dalam penelitiannya, Tukimun (2006) menyatakan bahwa pembelajaran yang masih bersifat teacher centered menyebabkan suasana belajar yang kurang menarik dan kurang komunikatif. Lebih lanjut Sumantri (dalam Nur, 2005) menyatakan bahwa pembelajaran IPS yang diberikan di sekolahsekolah sangat membosankan. Sehingga siswa tidak antusias untuk terlibat dalam proses pembelajaran yang berakibat pada pembelajaran yang kurang menarik.

Hasil penelitian Suwarna (2009) menunjukkan beberapa kelemahan dalam pembelajaran IPS yang terjadi di sekolah yaitu: proses pembelajaran lebih menekankan pada aspek pengetahuan, kegiatan pembelajaran bersifat teacher centred, materi ajar tidak berupa informasi yang dapat dijadikan pengembangan nilai dan sikap dan terdapat kecendrungan IPS sebagai pelajaran menghafal dari pada budaya berpikir kritis. Hal ini berakibat pada rendahnya hasil belajar serta menurunnya moralitas siswa.

\section{Hakikat Hasil Belajar IPS}

Pada dasarnya puncak dari proses pembelajaran adalah hasil yang ditunjukkan dalam bentuk nilai atau skor yang diperoleh siswa. Dari sinilah di dapat informasi tentang berhasil atau tidaknya proses pembelajaran dalam mencapai kompetensi materi ajar. Lebih lanjut Djamrah dan Zain (2010) menyatakan bahwa ada dua indikator keberhasilan proses pembelajaran yaitu: (1) Daya serap terhadap bahan pengajaran yang diajarkan mencapai prestasi tinggi, baik secara individual maupun kelompok. (2) Perilaku yang digariskan dalam tujuan pengajaran/instruksional khusus (TIK) telah dicapai oleh siswa, baik secara individual maupun kelompok.

Menurut Dimyati dan Mudjiono (2006) hasil belajar merupakan hal yang dapat dipandang dari dua sisi yaitu sisi siswa dan sisi pengajar. Dari sisi siswa; hasil belajar merupakan tingkat perkembangan mental yang lebih baik bila dibandingkan pada saat sebelum belajar (perubahan mental). Tingkat perkembangan mental tersebut terwujud pada jenis-jenis ranah kognitif, afektif dan psikomotorik. Sedangkan dari sisi pengajar; hasil belajar merupakan saat terselesaikannya bahan pelajaran.

Lebih lanjut Romiszowski (dalam Nasution, 2009), menyatakan bahwa hasil belajar di kelompokkan kedalam dua macam yaitu: keterampilan dan pengetahuan. Keterampilan terdiri dari empat kategori: (1) keterampilan untuk berfikir dan keterampilan kognitif. (2) keterampilan untuk bertindak atau keterampilan motorik. (3) keterampilan bereaksi atau bersikap. (4) keterampilan berinteraksi. Sedangkan pengetahuan juga di bagi kedalam empat kategori: (1) pengetahuan tentang fakta. (2) pengetahuan tentang prosedur. (3) pengetahuan tentang konsep. (4) pengetahuan tentang prinsip.

\section{Hakikat Strategi Pembelajaran}

Dick \& Carey (2015) mendefinisikan strategi pembelajaran sebagai suatu pendekatan dalam mengolah secara sistematis pembelajaran sehingga siswa dapat menguasai isi pembelajaran atau mencapai tujuan yang diharapkan. Selanjutnya Miarso (2009) menyebutkan bahwa strategi pembelajaran adalah pendekatan menyeluruh pembelajaran dalam suatu sistem pembelajaran, yang berupa pedoman umum dan kerangka kegiatan untuk mencapai tujuan umum pembelajaran.

Sudrajat (dalam Sanjaya, 2010), menerangkan bahwa terdapat empat unsur strategi pembelajaran yaitu: (1) Menetapkan spesifikasi dan kualifikasi tujuan pembelajaran yakni perubahan profil perilaku dan pribadi siswa. (2) Mempertimbangkan dan memilih sistem pendekatan pembelajaran yang dipandang paling efektif. (3) Mempertimbangkan dan menetapkan langkahlangkah atau prosedur, metode dan teknik pembelajaran. (4) Menetapkan norma-norma dan batas minimum ukuran keberhasilan atau kriteria dan ukuran baku keberhasilan.

Terdapat berbagai tipe model pembelajaran yang dikemukan para ahli, salah satunya adalah model pembelajaran kooperatif yang tujuan utamanya memaksimalkan aktivitas siswa dalam proses pembelajaran. Isjoni (2009) menyatakan bahwa pembelajaran kooperatif adalah salah satu bentuk pembelajaran yang berdasarkan faham konstruktivis. Hal senada juga diungkapkan Lungdren (dalam Isjoni, 2009) bahwa terdapat tujuh unsur dasar pembelajaran kooperatif yaitu: (1) para siswa memiliki persepsi bahwa mereka "tenggelam atau berenang bersema" (2) para siswa harus 
memiliki tanggungjawab terhadap anggota kelompoknya dalam mempelajari materi yang dihadapi (3) para siswa harus berpandangan bahwa mereka semua memiliki tujuan yang sama (4) para siswa membagi tugas dan berbagi tanggung jawab diantara para anggota kelompok (5) para siswa diberikan satu evaluasi atau penghargaan yang akan ikut berpengaruh terhadap evaluasi kelompok (6) para siswa berbagi kepemimpinan sementara mereka memperoleh keterampilan bekerjasama selama belajar (7) setiap siswa akan diminta mempertanggungjawabkan secara individual materi yang ditangani dalam kelompok kooperatif.

Didalam model pembelajaran kooperatif tersebut terdapat delapan strategi pembelajaran yaitu Student Teams Achievement Division (STAD), Kelompok Ahli (Jigsaw), Investigasi Kelompok (Kelompok Investigasi), Think Pair Share (TPS), Nambered Head Together (NHT), Teams Games Tournament (TGT), Rotation Trio Exchange (RTE) dan Group Resume (GR). Namun dalam penelitian ini yang diuji pengaruhnya terhadap hasil belajar IPS hanya strategi pembelajaran NHT dan STAD.

Desain strategi pembelajaran NHT dan STAD menggunakan desain pembelajaran yang terdiri dari empat komponen utama yaitu: urutan kegiatan instruksional (pendahuluan, kegiatan inti, dan penutup), metode, media dan waktu.

\section{Strategi Pembelajaran Numbered Head Together (NHT)}

NHT merupakan salah satu tipe dari model pembelajaran kooperatif yang menekankan pada struktur khusus yang dirancang untuk mempengaruhi pola interaksi siswa dan memiliki tujuan untuk meningkatkan penguasaan akademik. Model pembelajaran kooperatif yang dikembangkan oleh Spencer Kagan ini digunakan untuk melibatkan lebih banyak siswa dalam menelaah dan memahami materi yang tercakup dalam suatu pelajaran. Pembelajaran kooperatif NHT merupakan model pembelajaran kooperatif yang membagi siswa ke dalam kelompok-kelompok kecil dan setiap siswa di dalam kelompok tersebut mendapatkan sebuah nomor, kemudian secara acak guru akan memanggil nomor dari siswa.

Strategi pembelajaran ini pada hakikatnya adalah pengembangan dari diskusi kelompok yang memiliki ciri khas penghunjukkan seorang siswa yang mewakili kelompoknya tanpa memberitahukan terlebih dahulu. Hal ini dipertegas oleh pendapat Nur (2005) dengan cara tersebut akan menjamin keterlibatan total semua siswa dan merupakan upaya yang sangat baik untuk meningkatkan tanggung jawab individual dalam diskusi kelompok.

Lebih lanjut Lie (2002) menyatakan bahwa prosedur teknik numbered head together adalah saat pemanggilan siswa untuk menjawab atau melakukan sesuatu yang dipanggil adalah nomor kepala dari salah satu kelompok secara acak. Hal ini akan membuat semua siswa harus siap dan penghargaan akan diberikan jika jawaban benar untuk nilai kelompok. Teknik ini memberikan kesempatan kepada semua siswa dalam kelompok untuk saling memberikan ide dan mempertimbangkan jawaban yang paling tepat, mendorong siswa untuk meningkatkan semangat kerjasama mereka.

Totalitas keterlibatan siswa di sini tentunya akan berdampak positif bagi prestasi belajar siswa, karena siswa dipaksa untuk berusaha memahami konsep-konsep, berinteraksi dengan sesama teman serta mencari penyeselesaian terhadap permasalahn yang sajikan oleh guru. Ibrahim, dkk (2000) mengungkapkan bahwa dengan belajar kooperatif akan dapat memperbaiki prestasi siswa atau tugas-tugas akademik serta memberikan keuntungan baik pada siswa kelompok bawah maupun kelompok atas yang bekerjasama menyelesaikan tugas-tugas akademis.

Lebih lanjut Ibrahim, dkk (2000) mengemukakan tiga tujuan yang hendak dicapai dalam pembelajaran kooperatif dengan tipe NHT yaitu : (1) Hasil belajar akademik stuktural; bertujuan untuk meningkatkan kinerja siswa dalam tugas-tugas akademik. (2) Pengakuan adanya keragaman; bertujuan agar siswa dapat menerima teman-temannya yang mempunyai berbagai latar belakang. (3) Pengembangan keterampilan sosial; bertujuan untuk mengembangkan keterampilan sosial siswa. Keterampilan yang di maksud antara lain berbagi tugas, aktif bertanya, menghargai pendapat orang lain, mau menjelaskan ide atau pendapat, bekerja dalam kelompok dan sebagainya. 


\section{Strategi Pembelajaran Student Teams Achievement Division (STAD)}

Pembelajaran kooperatif tipe (STAD) merupakan salah satu strategi pembelajaran yang dikembangkan oleh Robert E. Slavin yang menekankan adanya aktivitas dan interaksi di antara siswa untuk saling memotivasi dan saling membantu dalam menguasai materi pelajaran guna mencapai prestasi yang maksimal. Fokus dari strategi ini adalah keberhasilan pencapaian kompetensi oleh kelompok dengan asumsi bahwa kompetensi hanya dapat dicapai jika setiap anggota kelompok berusaha menguasai materi ajar yang menjadi pembahasan.

Terdapat tiga hal yang paling utama dalam strategi pembelajaran ini yaitu : Pertama, penghargaan terhadap kelompok, hal ini dapat diperoleh jika kelompok berhasil memperoleh poin tertinggi dalam periode tertentu. Kedua, pertanggungjawaban individu, di mana terdapat ketergantungan kelompok kepada individu. Artinya setiap anggota kelompok harus mampu dan bersedia menjadi tutor bagi rekannya agar siap menghadapi soal atau kuis yang diberikan. Ketiga, adanya kesempatan yang sama untuk sukses.

Lebih lanjut Slavin (2008) mengemukakan bahwa strategi pembelajaran STAD terdiri atas lima komponen utama yaitu:

1. Presentasi Kelas.

Presentasi kelas dapat dilakukan melalui pengajaran secara langsung dengan menekankan pada hal-hal pokok dalam materi ajar. Kemudian siswa harus mendalaminya melalui pembelajaran dalam kelompok.

2. Kerja Kelompok

Kelompok terdiri dari 4 atau 5 orang siswa mempunyai karakteristik yang berbedabeda atau heterogen baik dalam penguasaan materi, jenis kelamin, maupun suku serta memiliki kemampuan kelompok yang homogen (relatif sama). Fungsi utama dari kelompok adalah memastikan bahwa semua anggota kelompok telah menguasai materi yang diberikan dan juga untuk mempersiapkan anggota kelompok dalam menghadapi kuis, sehingga semua anggota kelompok dapat mengerjakan dengan baik. Dalam hal ini, siswa mendiskusikan masalah atau kesulitan yang ada dan menyatukan konsep diantara anggota kelompok.
3. Pemberian Kuis

Ketika kuis dilaksanakan siswa tidak diperbolehkan saling membantu dalam mengerjakan kuis. Artinya setiap anggota kelompok harus bertanggung jawab secara individu dalam menguasai materi ajar yang diberikan. Namun demikian tiap siswa memiliki skor awal yang didapat dari hasil ujian semester atau nilai ulangan materi ajar sebelumnya, selanjutnya siswa akan mengumpulkan poin untuk kelompok mereka berdasarkan tingkat kenaikan skor kuis siswa kemudian dibandingkan dengan skor awal mereka. Perhitungan skor perkembangan individu yang didasarkan pada skor awal.

\section{Hakikat Kecerdasan Ganda (Multiple Intellegences)}

Kecerdasan (Intelligence) memiliki pengertian yang sangat luas. Para ahli psikologi mengartikan kecerdasan sebagai keseluruhan kemampuan individu untuk memperoleh pengetahuan, menguasainya dan mempraktekkannya dalam pemecahan suatu masalah. Menurut Safaria (2005), kecerdasan merupakan kemampuan yang dimiliki seseorang untuk melihat suatu masalah lalu menyelesaikannya atau membuat sesuatu yang dapat berguna bagi orang lain.

Pembahasan tentang kecerdasan telah banyak dikemukakan oleh pakar seperti yang telah dijelaskan di atas. Sedang Armstrong menambahkan satu teori lagi yang banyak dikaji, yaitu dari Guillford dengan teori Structure Intelligence. Menurut Amstrong (2004), kecerdasan adalah kemampuan untuk menangkap situasi baru serta kemampuan untuk belajar dari pengalaman masa lalu seseorang.

Pada perkembangan selanjutnya para pakar kecerdasan, antara lain Goleman dengan teori Emotional Intelligence dan Gardner dengan teori Multiple Intelligence (Gunawan, 2003). Secara singkat mengemukakan defenisi kecerdasan yang dinyatakan sebagai potensi atau kemampuan seseorang yang perlu dikembangkan.

Seiring dengan perkembangan teori kecerdasaan tersebut, telah terjadi pergeseran dari kecerdasan sebagai kemampuan umum beralih kepada kecerdasan sebagai kemampuan khusus yang memiliki beberapa bagian atau bahkan banyak domain. Peralihan tersebut menurut Semiawan (2004), kelihatan dalam pengembangan individu yang mengacu kepada 
pendapat yang menunjukkan bahwa perkembangan manusia diwujudkan melalui ragam aspek yang berbeda. Hal tersebut merupakan pertanda bahwa teori kecerdasan ganda (multiple intelligence) mulai mendapat perhatian untuk digunakan sebagai acuan dalam berbagai aktivitas untuk memacu perkembangan manusia termasuk aktivitas pembelajaran di sekolah-sekolah. Lebih lanjut Gardner (1993), berkeyakinan bahwa semua manusia memiliki lebih dari satu kecerdasan (inteligensi) melainkan group abilities. Dengan demikian dapat dinyatakan bahwa kecerdasan ganda adalah semua daya atau kemampuan yang dapat berkembang melalui pembelajaran yang terdiri dari delapan aspek kecerdasan, yaitu:

1. Kecerdasan Logika Matematika; Kemampuan untuk meneliti pola-pola, kategori-kategori, dan hubungan-hubungan dengan cara memanipulasi objek-objek dan simbol-simbol dan mencobanya dengan cara yang terkontrol dan teratur.

2. Kecerdasan Bahasa; Kemampuan menggunakan bahasa untuk membangkitkan atau memberi semangat, meyakinkan, mendorong, dan menyampaikan informasi.

3. Kecerdasan Intrapersonal; Kecerdasan untuk memahami perasaan, mimpi-mimpi dan ide-ide pribadi.

4. Kecerdasan Interpersonal; Kemampuan untuk memahami dan berinteraksi dengan orang lain.

5. Kecerdasan Kinestetis; Kemampuan untuk menggunakan ketrampilan motorik kasar dan halus di bidang olahraga.

6. Kecerdasan Visual-Spasial; Kemampuan untuk melihat serta menciptakan perbedaan, keseimbangan dan komposisi di dalam tayangan visual atau ruang.

7. Kecerdasan Musikal; Kemampuan untuk menikmati, menampilkan dan membuat gabungan lagu/musik termasuk kepekaan dalam menentukan nada, irama, dan merespon elemen-elemen tersebut secara emosional/tersirat terhadap dampak emosional dari elemen-elemen tersebut.

8. Kecerdasan Naturalis; Kemampuan untuk mengenal flora dan fauna, memiliki ketertarikan dengan alam dan fenomenanya, melibatkan pengetahuan yang muncul ketika berinteraksi dengan alam.

Mengacu pada pendapat Garnerd dan begitu kompleksnya permasalahan dalam kecerdasan ganda maka penelitian hanya membandingkan dua aspek kecerdasan ganda yaitu: kecerdasan intrapersonal dan kecerdasan interpersonal.

\section{Kecerdasan Intrapersonal}

Kecerdasan intrapersonal menurut Gardner (1993), merupakan kemampuan memahami hal-hal yang berkaitan dengan perasaan-perasaan yang ada pada diri sendiri, seperti perasaan senang ataupun sedih, apa yang dapat ia lakukan, apa yang ingin ia lakukan, bagaimana ia bereaksi terhadap hal-hal tertentu, hal-hal yang mana yang perlu dihindari, dan hal-hal yang mana yang didekati. Sedang Lazear (2000), menyatakan bahwa kecerdasan intrapersonal merupakan kemampuan introspeksi diri yang membuka peluang untuk merefleksi diri sehingga menyadari semua aspek dalam diri, seperti pengetahuan tentang perasaan sendiri, proses berpikir, refleksi diri dan rasa tentang hasrat yang dimiliki yang bertumpu pada dua hal, yaitu identitas diri dan kemampuan (ability) untuk mengenal kekuatan dan kelemahan diri sendiri. Kemudian Amstrong (2004), mengemukakan bahwa kecerdasan intrapersonal merupakan kemampuan memahami diri sendiri dan bertindak berdasarkan pemahaman tersebut.

Ketiga pendapat tersebut menunjukkan bahwa kecerdasan intrapersonal berkaitan dengan

Lebih lanjut Sujiono dan Sujiono (2010) mengemukakan bahwa terdapat beberapa cara untuk mengembangkan kecerdasan intrapersonal yaitu: (1) menciptakan citra diri yang positif, "aku anak baik". (2) menampilkan sikap hangat tapi tegas sehingga anak tetap dapat memiliki sikap hormat.(3) ciptakan suasana serta situasi yang kondusif. Dengan kata lain kecerdasan intrapersonal adalah kemampuan untuk mengenali diri sendiri dengan memiliki konsep serta citra diri yang positif atau alat untuk memberikan kontrol dan intropeksi diri dalam menjalani kehidupan sehingga terbentuklah kepribadian yang tidak terombang ambing oleh pengaruh-pengaruh eksternal.

\section{Kecerdasan Interpersonal}

Menurut Suarca, $d k k$ (2005), memiliki interaksi yang baik dengan orang lain, pintar menjalin hubungan sosial, serta mampu mengetahui dan menggunakan beragam cara saat berinteraksi adalah ciri-ciri kecerdasan interpersonal yang menonjol. Pada dasarnya, 
anak-anak akan belajar menyesuaikan diri dengan tuntutan sosial dan menjadi pribadi yang mampu berinteraksi dengan lingkungan sosialnya, hal ini bergantung pada empat faktor. Pertama, faktor kesempatan bersosialisasi. Kedua, mampu menampilkan topik yang dapat dipahami dan menarik bagi orang lain tapi pembicaraan yang bersifat sosial, tidak bersifat egosentrik dan dapat diterima oleh lingkungan sosialnya. Ketiga, anak harus mempunyai motivasi, bergantung pada tingkat kepuasan yang diperoleh dari aktivitas sosial anak. Jika ia memperoleh kesenangan melalui hubungan sosial dengan orang maka iapun akan mengulangi perilaku tersebut. Keempat, metode belajar saat berinteraksi sosial dengan orang lain yang efektif, adalah melalui teladan yang diberi oleh orang tua ataupun pendidik di rumah dan di sekolah (Suarca, $d k k, 2005$ ).

Salah seorang psikolog dari Inggris, NK Humphrey dikutip dari Amstrong (2004), mengatakan kecerdasan interpersonal yang merupakan bagian dari kemampuan sosial ini, merupakan hal penting dari kecerdasan manusia karena manfaat terbesar dari pikiran manusia adalah untuk mempertahankan kehidupan sosial dengan cara yang efektif. Lebih lanjut menurut Anderson (dalam Safaria, 2005), kecerdasan interpersonal mempunyai tiga dimensi, yaitu: Social sensitivity, Social insight, dan Social communication. Ketiga dimensi tersebut merupakan satu kesatuan yang utuh dan ketiganya saling mengisi satu sama lainnya.

Masalah pada penelitian ini adalah: (1) Apakah hasil belajar kelompok siswa yang diajar dengan menggunakan strategi pembelajaran NHT lebih tinggi dibandingkan daripada hasil belajar kelompok siswa yang diajar dengan menggunakan strategi pembelajaran STAD?; (2) Apakah kelompok siswa yang memiliki kecerdasan interpersonal memperoleh hasil belajar IPS lebih tinggi dibandingkan dengan kelompok siswa yang memiliki kecerdasan intrapersonal?; dan (3) Apakah ada interaksi antara strategi pembelajaran (NHT dan STAD) dan kecerdasan ganda (kecerdasan intrapersonal dan kecerdasan interpersonal) terhadap hasil belajar IPS?

\section{METODE}

Penelitian ini dilaksanakan di SMK Negeri I Meranti Kabupaten Asahan, semester genap. Populasi dalam penelitian ini adalah seluruh siswa kelas XI yang berjumlah 170 orang. Terdiri dari 3 kelas dengan Progam studi Tehnik Komputer Jaringan (TKJ) dan 2 kelas dengan program studi Tehnik Perbaikan Bodi Otomotif (TPBO). Teknik pengambilan sampel dilakukan secara acak (clustre random sampling). Dari hasil pengundian sampel tersebut maka diperoleh sampel yang terdiri dari dua kelas (kelas XI TKJ 2 dan XI TKJ 3). Kelas XI TKJ 2 sebanyak 40 siswa diberikan perlakuan penerapan strategi pembelajaran NHT dan kelas XI TKJ 3 sebanyak 40 siswa diberikan perlakuan penerapan strategi pembelajaran STAD.

Metode yang digunakan dalam penelitian ini adalah metode penelitian eksperimen semu (quasi eksperiment). Penelitian dilakukan dengan menggunakan strategi pembelajaran NHT yang dibandingkan dengan strategi pembelajaran STAD sebagai variabel bebas. Kecerdasan ganda yaitu kecerdasan intrapersonal dan kecerdasan interpersoanal sebagai variabel moderator sedangkan hasil belajar IPS sebagai variabel terikat.

Desain yang digunakan dalam penelitian ini adalah desain faktorial $2 \times 2$. Dalam penelitian ini terdapat 2 kelompok sampel, seperti pada Tabel 1.

Tabel 1. Desain Penelitian

\begin{tabular}{|c|c|c|c|}
\hline $\begin{array}{ll}\text { Kecerdasan } & \text { Strategi Pembelajaran } \\
\end{array}$ & $\begin{array}{l}\text { NHT } \\
\left(\mathrm{A}_{1}\right)\end{array}$ & $\begin{array}{l}\text { STAD } \\
\left(\mathrm{A}_{2}\right)\end{array}$ & \\
\hline $\begin{array}{c}\text { Interpersonal } \\
\left(\mathrm{B}_{1}\right)\end{array}$ & $\mu \mathrm{A}_{1} \mathrm{~B}_{1}$ & $\mu \mathrm{A}_{2} \mathrm{~B}_{1}$ & $\mu \mathrm{B}_{1}$ \\
\hline $\begin{array}{c}\text { Intrapersonal } \\
\left(\mathrm{B}_{2}\right) \\
\end{array}$ & $\mu \mathrm{A}_{1} \mathrm{~B}_{2}$ & $\mu \mathrm{A}_{2} \mathrm{~B}_{2}$ & $\mu \mathrm{B}_{2}$ \\
\hline & $\mu \mathrm{A}_{1}$ & $\mu \mathrm{A}_{2}$ & \\
\hline
\end{tabular}

Keterangan:

$\mu \mathrm{A}_{1}$ : Hasil belajar IPS siswa diajar dengan strategi pembelajaran NHT $\mu \mathrm{A}_{2}$ : Hasil belajar IPS siswa diajar dengan strategi pembelajaran STAD

$\mu \mathrm{B}_{1} \quad$ : Hasil belajar IPS siswa mempunyai kecerdasan interpersonal 
$\mu \mathrm{B}_{2} \quad$ : Hasil belajar IPS siswa mempunyai kecerdasan intrapersonal

$\mu \mathrm{A}_{1} \mathrm{~B}_{1}$ : Hasil belajar IPS siswa diajar dengan strategi pembelajaran NHT memiliki kecerdasan interpersonal

$\mu \mathrm{A}_{1} \mathrm{~B}_{2}$ : Hasil belajar IPS siswa diajar dengan strategi pembelajaran NHT memiliki kecerdasan intrapersonal

$\mu \mathrm{A}_{2} \mathrm{~B}_{1}$ : Hasil belajar IPS siswa diajar dengan strategi pembelajaran STAD memiliki kecerdasan interpersonal

$\mu \mathrm{A}_{2} \mathrm{~B}_{2}$ : Hasil belajar IPS siswa diajar dengan strategi pembelajaran STAD memiliki kecerdasan intrapersonal

Untuk melakukan analisis data digunakan teknik analisis deskriptif dan teknik analisis inferensial. Teknik analisis statistik deskriptif dimaksudkan untuk mendeskripsikan data penelitian dengan membuat tabel distribusi frekuensi dan histogram. Dari tabel tersebut dihitung nilai rata-rata (mean), median, modus, standar deviasi dan kecenderungan data. Teknik analisis statistik inferensial digunakan untuk menguji hipotesis penelitian dengan menggunakan teknik analisis varians (ANAVA dua jalur) dengan uji $\mathrm{F}$ pada taraf signifikan 0,05 .

Jika hasil pengujian menunjukkan terdapatnya interaksi antara strategi pembelajaran dan kecerdasan ganda maka perlu dilakukan uji lanjut dengan uji Scheffe. Uji Scheffe digunakan karena jumlah siswa dalam tiap kelompok atau sel tidak sama besar. Sebelum pengujian hipotesis dilakukan uji persyaratan, yakni uji normalitas data penelitian dengan teknik Liliefors, kemudian dilanjutkan dengan uji homogenitas data dengan menggunakan uji F dan Barlett. Untuk memberi arah dalam analisis data, maka hipotesis perlu dinyatakan dalam rumus statistik.

Adapun rumusan hipotesis statistiknya dinyatakan sebagai berikut:

Hipotesis pertama:

$$
\begin{array}{ll}
\mathrm{H}_{\mathrm{o}}: & \mu \mathrm{A}_{1} \leq \mu \mathrm{A}_{2} \\
\mathrm{H}_{\mathrm{a}}: & \mu \mathrm{A}_{1}>\mu \mathrm{A}_{2}
\end{array}
$$

Hipotesis kedua:

$$
\begin{array}{ll}
\mathrm{H}_{\mathrm{o}}: & \mu \mathrm{B}_{1} \leq \mu \mathrm{B}_{2} \\
\mathrm{H}_{\mathrm{a}}: & \mu \mathrm{B}_{1}>\mu \mathrm{B}_{2}
\end{array}
$$

Hipotesis ketiga:

$$
\begin{array}{ll}
\mathrm{H}_{\mathrm{o}}: & \mathrm{A}><\mathrm{B}=0 \\
\mathrm{H}_{\mathrm{a}}: & \mathrm{A}><\mathrm{B} \neq 0
\end{array}
$$

Keterangan :

$\mu \mathrm{A}_{1} \quad$ : Hasil belajar IPS siswa yang diajarkan dengan strategi pembelajaran NHT

$\mu \mathrm{A}_{2} \quad$ : Hasil belajar IPS siswa yang diajarkan dengan strategi pembelajaran STAD

$\mu \mathrm{B}_{1} \quad$ : Hasil belajar IPS siswa yang memiliki kecerdasan interpersonal

$\mu \mathrm{B}_{2} \quad$ : Hasil belajar IPS siswa yang memiliki kecerdasan intrapersonal

A $><$ B : Interaksi antara strategi pembelajaran dengan kecerdasan ganda

\section{HASIL DAN PEMBAHASAN \\ Hasil}

Deskripsi Data Hasil Penelitian

Data-data hasil temuan penelitian dikelompok berdasarkan interaksi antara strategi pembelajaran dengan kecerdasan ganda siswa. Perbandingan kelompok data-data hasil belajar siswa berdasarkan temuan penelitian, secara ringkas dirangkum pada Tabel 2.

Tabel 2. Perbandingan Data Hasil Belajar IPS Siswa Berdasarkan Strategi Pembelajaran dan Kecerdasan Ganda Siswa

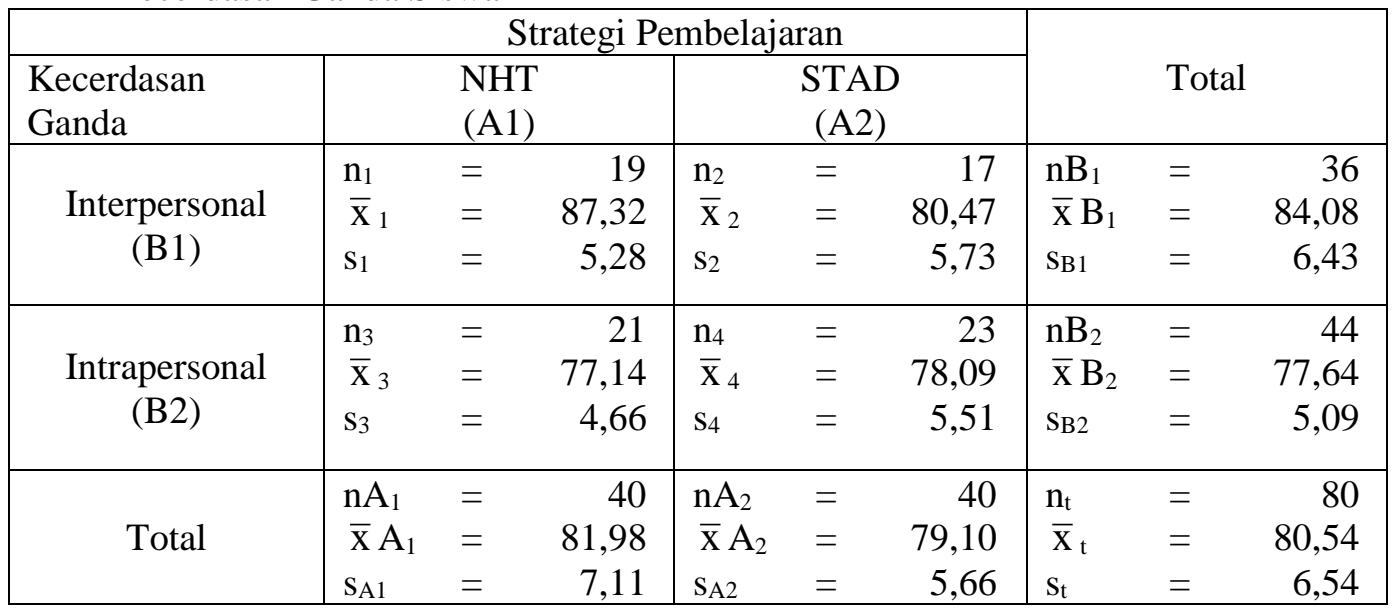


Pengujian hipotesis dilakukan menggunakan teknik analisis varians (anava) dua jalur dengan desain faktorial $2 \times 2$. Hasil perhitungan analisis varians dua jalur, secara ringkas dirangkum pada Tabel 3.

Tabel 3. Rangkuman Hasil Pengujian Analisis Varians Dua Jalur

\begin{tabular}{|l|c|c|r|r|c|}
\hline \multicolumn{1}{|c|}{ Sumber Variasi } & $\mathrm{dk}$ & \multicolumn{1}{c|}{$\mathrm{JK}$} & $\mathrm{RK}=\mathrm{JK} / \mathrm{dk}$ & \multicolumn{1}{|c|}{$\mathrm{Fh}$} & $\mathrm{Ft}_{\alpha=0,05}$ \\
\hline Antar Kolom (A) & 1 & 165,313 & 165,313 & 5,896 & 3,98 \\
Antar Baris (B) & 1 & 822,956 & 822,956 & 29,354 & 3,98 \\
Interaksi (AB) & 1 & 264,881 & 264,881 & 9,448 & 3,98 \\
\hline Galat (Dalam) & 76 & 2130,738 & 28,036 & & \\
\hline
\end{tabular}

Perbedaan Hasil Belajar Siswa yang Dibelajarkan dengan Strategi Pembelajaran NHT dengan Strategi Pembelajaran STAD adalah:

Adapun hipotesis statistik, yang diuji

$$
\begin{aligned}
& \mathrm{H}_{\mathrm{o}}: \mu \mathrm{A}_{1} \leq \mu \mathrm{A}_{2} \\
& \mathrm{H}_{\mathrm{a}}: \mu \mathrm{A}_{1}>\mu \mathrm{A}_{2}
\end{aligned}
$$

Hasil penelitian diperoleh rata-rata hasil belajar IPS siswa yang diajarkan dengan strategi pembelajaran NHT sebesar 81,98 dan hasil belajar IPS untuk kelompok siswa yang diajarkan dengan strategi pembelajaran STAD diperoleh rata-rata sebesar 79,10.

Berdasarkan hasil pada Tabel 25, diperoleh nilai $F_{\text {hitung }}$ sebesar 5,896. Pada taraf signifikansi $\alpha=0,05$ diperoleh $\mathrm{F}_{0,05}(1 ; 76)=3,98$. Karena $F_{\text {hitung }}>F_{\text {tabel }}$ yaitu 5,896 $>3,98$ maka terima $\mathrm{H}_{\mathrm{a}}$ sehingga disimpulkan hasil belajar IPS siswa yang diajar dengan strategi pembelajaran NHT lebih tinggi dibandingkan hasil belajar siswa yang diajar dengan strategi pembelajaran STAD.

Perbedaan Hasil Belajar Siswa yang Memiliki Kecerdasan Interpersonal dengan Kecerdasan Intrapersonal adalah:

Adapun hipotesis statistik, yang diuji

$$
\begin{aligned}
& \mathrm{H}_{\mathrm{o}}: \mu \mathrm{B}_{1} \leq \mu \mathrm{B}_{2} \\
& \mathrm{H}_{\mathrm{a}}: \mu \mathrm{B}_{1}>\mu \mathrm{B}_{2}
\end{aligned}
$$

Hasil temuan penelitian diperoleh ratarata hasil belajar IPS untuk kelompok siswa yang memiliki kecerdasan interpersonal sebesar 84,08 dan untuk kelompok siswa yang memiliki kecerdasan intrapersonal diperoleh rata-rata hasil belajar sebesar 77,64.

Berdasarkan hasil pada Tabel 25, diperoleh nilai $F_{\text {hitung }}$ sebesar 29,354. Pada taraf signifikansi $\alpha=0,05$ diperoleh $\mathrm{F}_{0,05}(1 ; 76)=3,98$. Karena $F_{\text {hitung }}>F_{\text {tabel }}$ yaitu 29,354 > 3,98 maka terima $\mathrm{H}_{\mathrm{a}}$ sehingga disimpulkan bahwa hasil belajar IPS siswa yang memiliki kecerdasan interpersonal lebih tinggi dibandingkan hasil belajar IPS siswa yang memiliki kecerdasan intrapersonal.

Interaksi Antara Strategi Pembelajaran dan Kecerdasan Ganda Siswa Terhadap Hasil Belajar IPS adalah:

Adapun hipotesis statistik, yang diuji

$$
\begin{aligned}
& \mathrm{H}_{\mathrm{o}}: \mu \mathrm{A}><\mu \mathrm{B}=0 \\
& \mathrm{H}_{\mathrm{a}}: \mu \mathrm{A}><\mu \mathrm{B} \neq 0
\end{aligned}
$$

Hasil temuan penelitian diperoleh ratarata hasil belajar IPS kelompok siswa yang diajarkan strategi pembelajaran NHT yang memiliki kecerdasan interpersonal sebesar 87,32; kelompok siswa yang diajarkan dengan strategi pembelajaran NHT yang memiliki kecerdasan intrapersonal sebesar 77,14; kelompok siswa yang diajarkan dengan strategi pembelajaran STAD yang memiliki kecerdasan interpersonal sebesar 80,47; dan kelompok siswa yang diajarkan dengan strategi pembelajaran STAD yang memiliki kecerdasan intrapersonal sebesar 78,09. Selanjutnya berdasarkan hasil analisis varians pada Tabel 25, diperoleh nilai $F_{\text {hitung }}>F_{\text {tabel }}$ yaitu 9,448 > 3,98 sehingga terima $\mathrm{H}_{a}$ atau tolak $\mathrm{H}_{0}$ dan disimpulkan terdapat interaksi antara strategi pembelajaran dan kecerdasan ganda siswa tehadap hasil belajar IPS siswa.

Hasil pengujian yang ketiga menyatakan terdapat interaksi antara strategi pembelajaran dan kecerdasan ganda siswa terhadap hasil belajar IPS siswa. Karenanya, perlu dilakukan pengujian lanjutan untuk mengetahui rata-rata nilai kelompok mana yang memberi pengaruh lebih baik terhadap hasil belajar IPS siswa. Uji lanjut dilakukan dengan uji Scheffe. 
Tabel 4. Rangkuman Hasil Uji Scheffe

\begin{tabular}{|c|c|c|c|}
\hline No. & $\begin{array}{c}\text { Perbandingan } \\
\text { Rata-rata Nilai } \\
\text { Kelompok }\end{array}$ & $\mathrm{F}_{\text {hitung }}$ & $\begin{array}{c}\mathrm{F}_{\text {tabel }} \\
(3) \mathrm{F}_{0,05} \\
3 ; 76\end{array}$ \\
\hline 1 & $\begin{array}{c}\mathrm{A}_{1} \mathrm{~B}_{1} \text { dengan } \\
\mathrm{A}_{1} \mathrm{~B}_{2}\end{array}$ & 36,872 & 8,16 \\
\hline 2 & $\begin{array}{c}\mathrm{A}_{1} \mathrm{~B}_{1} \text { dengan } \\
\mathrm{A}_{2} \mathrm{~B}_{1}\end{array}$ & 15,016 & 8,16 \\
\hline 3 & $\begin{array}{c}\mathrm{A}_{1} \mathrm{~B}_{1} \text { dengan } \\
\mathrm{A}_{2} \mathrm{~B}_{2}\end{array}$ & 31,617 & 8,16 \\
\hline 4 & $\begin{array}{c}\mathrm{A}_{1} \mathrm{~B}_{2} \text { dengan } \\
\mathrm{A}_{2} \mathrm{~B}_{1}\end{array}$ & 3,716 & 8,16 \\
\hline 5 & $\begin{array}{c}\mathrm{A}_{1} \mathrm{~B}_{2} \text { dengan } \\
\mathrm{A}_{2} \mathrm{~B}_{2}\end{array}$ & 0,353 & 8,16 \\
\hline 6 & $\begin{array}{c}\mathrm{A}_{2} \mathrm{~B}_{1} \text { dengan } \\
\mathrm{A}_{2} \mathrm{~B}_{2}\end{array}$ & 1,975 & 8,16 \\
\hline
\end{tabular}

Sesuai dengan kerangka berpikir, maka menunjukkan ada interaksi antara strategi pembelajaaran dan kecerdasan ganda terhadap hasil belajar siswa yaitu untuk kelompok siswa yang memiliki kecerdasan interpersonal diajarkan dengan strategi pembelajaran NHT lebih tinggi dari kelompok siswa yang memiliki kecerdasan interpersonal diajarkan dengan strategi pembelajaran STAD secara signifikan $(87,32>80,47)$ pada butir (b) uji Scheffe, dan untuk kelompok siswa yang memiliki kecerdasan intrapersonal diajarkan dengan strategi pembelajaran STAD hasil belajarnya secara signifikan tidak lebih tinggi daripada kelompok siswa yang memiliki kecerdasan intrapersonal diajarkan dengan strategi pembelajaran NHT $(78,09 \approx 77,14)$ pada butir (e) uji Scheffe.

Lebih jelasnya adanya interaksi antara strategi pembelajaran dan kecerdasan ganda siswa terhadap hasil belajar IPS siswa.

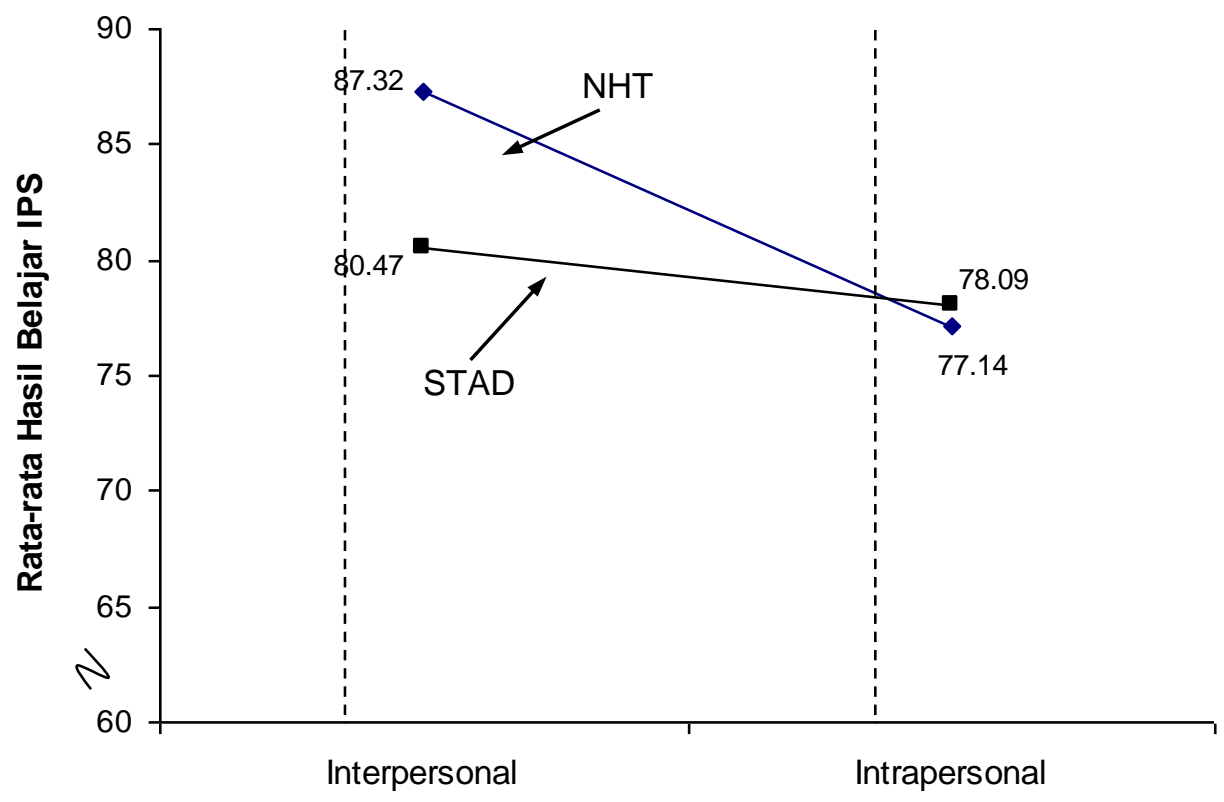

Kecerdasan Ganda

Gambar 1. Pola Interaksi Antara Strategi Pembelajaran dan Kecerdasan Ganda Terhadap Hasil Belajar IPS Siswa

\section{Pembahasan}

Perbedaan Hasil Belajar Siswa yang Diajarkan dengan Strategi Pembelajaran NHT dan STAD

Hasil temuan penelitian, diperoleh ratarata nilai hasil belajar IPS siswa yang diajarkan dengan strategi pembelajaran NHT sebesar 81,98 sedangkan nilai rata-rata hasil belajar IPS siswa yang diajarkan dengan strategi pembelajaran STAD sebesar 79,10. Hasil pengujian hipotesis diperoleh nilai $F_{\text {hitung }}>F_{\text {tabel }}$ yaitu 5,896 > 3,98 sehingga hipotesis pertama yang diajukan diterima dan disimpulkan bahwa hasil belajar IPS siswa yang diajar dengan strategi pembelajaran NHT lebih tinggi daripada hasil belajar siswa yang diajar dengan strategi pembelajaran STAD. Berdasarkan ratarata nilai menunjukkan bahwa strategi pembelajaran NHT memberikan pengaruh sebesar 3,6\% lebih tinggi dibandingkan strategi pembelajaran STAD.

Kesimpulan di atas juga didukung penelitian yang dilakukan Akbar (2010) yang 
menyimpulkan bahwa penerapan model pembelajaran tipe STAD dapat meningkatkan hasil belajar mata pelajaran komunikasi pada pokok bahasan melakukan komunikasi tertulis. Penelitian Yuliati, $d k k$ (2012), menyimpulkan bahwa ada perbedaan hasil belajar siswa dalam pembelajaran Akuntansi antara siswa yang pembelajarannya menggunakan model NHT dan STAD pada kelas X AK SMK YP Serdang Tanjung Bintang, hasil belajar siswa yang diajar dengan NHT secara keseluruhan menunjukkan lebih tinggi dibandingkan dengan siswa yang diajar dengan STAD. Selanjutnya penelitian Khoiriyah, dkk (2011), menyimpulkan bahwa terdapat perbedaan hasil belajar kimia antara siswa yang diberi metode NHT dengan metode STAD dan metode NHT dapat memberikan hasil belajar kimia yang lebih tinggi daripada metode STAD.

Berdasarkan hasil dan temuan-temuan penelitian yang diperoleh, maka dapat diindikasikan bahwa strategi pembelajaran NHT memberikan pengaruh yang lebih baik dalam meningkatkan hasil belajar IPS siswa dibandingkan strategi pembelajaran STAD. Dengan demikian, berdasarkan hasil penelitian yang telah dilakukan diperoleh bahwa hasil belajar IPS siswa yang diajarkan dengan strategi pembelajaran NHT lebih tinggi dibandingkan siswa yang diajarkan dengan strategi pembelajaran STAD.

Perbedaan Hasil Belajar Siswa yang Memiliki Kecerdasan Interpersonal dan Intrapersonal

Hasil tabulasi dan temuan penelitian diperoleh rata-rata hasil belajar IPS siswa yang memiliki kecerdasan interpersonal (baik yang diajar dengan strategi pembelajaran NHT maupun STAD) sebesar 84,08. Sedangkan ratarata hasil belajar IPS siswa yang memiliki kecerdasan intrapersonal (baik yang diajar dengan strategi pembelajaran NHT maupun STAD) sebesar 77,64. Hasil pengujain hipotesis diperoleh nilai $F_{\text {hitung }}>F_{\text {tabel }}$ yaitu 29,354 > 3,98 sehingga hipotesis kedua yang diajukan diterima dan disimpulkan bahwa hasil belajar IPS siswa yang memiliki kecerdasan interpersonal lebih tinggi dibandingkan kelompok siswa yang memiliki kecerdasan intrapersonal. Berdasarkan rata-rata nilai siswa menunjukkan bahwa rata-rata hasil belajar IPS kelompok siswa yang memiliki kecerdasan interpersonal sebesar 8,3\% lebih tinggi dibandingkan kelompok siswa yang memiliki kecerdasan intrapersonal.
Kesimpulan tersebut di atas didukung oleh penelitian Munawaroh dan Lisfuroe'ah (2009), yang menyimpulkan bahwa terdapat perbedaan yang signifikan hasil belajar matematika antara kelompok siswa yang berkecerdasan interpersonal jika dibandingkan dengan kelompok siswa yang berkecerdasan intrapersonal.

Berdasarkan hasil temuan penelitian yang ada maka memberi indikasi bahwa kecerdasan ganda siswa berpengaruh terhadap hasil belajar yang dicapai siswa. Dengan demikian, dari hasil penelitian yang telah dilakukan diperoleh bahwa hasil belajar IPS siswa yang memiliki kecerdasan interpersonal lebih tinggi dibandingkan kelompok siswa yang memiliki kecerdasan intrapersonal.

Interaksi Antara Strategi Pembelajaran dan Kecerdasan Ganda Siswa Terhadap Hasil Belajar IPS

Hasil pengelompokkan data diperoleh rata-rata hasil belajar IPS untuk kelompok siswa yang memiliki kecerdasan interpersonal dengan strategi pembelajaran NHT sebesar 87,32 ; kelompok siswa yang memiliki kecerdasan intrapersonal diajarkan strategi pembelajaran NHT diperoleh rata-rata hasil belajar sebesar 77,14; kelompok siswa yang memiliki kecerdasan interpersonal diajarkan strategi pembelajaran STAD diperoleh rata-rata hasil belajar sebesar 80,47; sedangkan kelompok siswa yang memiliki kecerdasan intrapersonal diajarkan strategi pembelajaran STAD diperoleh rata-rata hasil belajar sebesar 78,09 .

Hasil pengujian hipotesis ketiga menggunakan uji ANAVA dua jalur diperoleh $F_{\text {hitung }}>F_{\text {tabel }}$ yaitu $9,448>3,98$ sehingga hipotesis ketiga yang diajukan diterima yang berarti terdapat interaksi antara strategi pembelajaran dan kecerdasan ganda siswa tehadap hasil belajar IPS siswa.

Kesimpulan tersebut di atas sekaligus mendukung penelitian Bukit (2008) yang menyimpulkan bahwa terdapat pengaruh yang signifikan antara strategi pembelajaran peta konsep diawal dan diakhir dengan kecerdasan ganda (intrapersonal dan interpersonal) terhadap hasil belajar Biologi, serta terdapat interaksi antara strategi pembelajaran peta konsep dan komunikasi ganda terhadap hasil belajar Biologi.

Berdasarkan rata-rata hasil belajar yang diperoleh siswa memberi indikasi bahwa 
kelompok siswa yang memiliki kecerdasan interpersonal akan memperoleh hasil belajar yang lebih baik jika diajarkan dengan strategi pembelajaran NHT dibandingkan strategi pembelajaran STAD. Dengan demikian, dari hasil temuan penelitian dan pengujian hipotesis terbukti bahwa ada pengaruh strategi pembelajaran dan kecerdasan ganda siswa terhadap hasil belajar IPS siswa baik secara terpisah maupun interaksi atau bersamaan.

\section{PENUTUP}

1. Hasil belajar IPS siswa yang diajar dengan menggunakan strategi pembelajaran NHT lebih tinggi dibandingkan hasil belajar siswa yang diajarkan dengan strategi pembelajaran STAD. Dengan demikian, dalam mengajarkan konsep-konsep IPS diharapkan guru dapat menggunakan strategi pembelajaran NHT agar belajar siswa jadi lebih menyenangkan dan bermakna sehingga siswa dapat memperoleh hasil belajar yang lebih baik.

2. Hasil belajar IPS siswa yang memiliki kecerdasan interpersonal lebih tinggi dibandingkan kelompok siswa yang memiliki kecerdasan intrapersonal. Oleh karena itu, dalam mengajarkan IPS hendaknya guru berusaha menumbuh kembangkan kecerdasan ganda siswa terutama kecerdasan interpersonal siswa.

3. Terdapat interaksi antara strategi pembelajaran dan kecerdasan ganda tehadap hasil belajar IPS siswa. Hal ini memberi makna bahwa interaksi antara strategi pembelajaran dan kecerdasan ganda siswa mempengaruhi hasil belajar IPS siswa. Berdasarkan nilai rata-rata siswa memberi indikasi bahwa kelompok siswa yang memiliki kecerdasan interpersonal lebih tepat diajarkan strategi pembelajaran NHT sedangkan siswa yang memiliki kecerdasan intrapersonal lebih tepat diajarkan strategi pembelajaran STAD.

\section{DAFTAR PUSTAKA}

Amstrong, Thomas. (2003). In Their Own Way: Discovering and Encouraging Your Child's Multiple Intelligences. (alih bahasa). Jakarta: Gramedia Pustaka Utama.

Amstrong, Thomas. (2004). Menerapkan Multiple Intelligences di Sekolah, (alih bahasa Yudhi Murtanto), Bandung: Kaifa.
Bukit, Julia Damaris. (2008). Pengaruh Strategi Pembelajaran Peta Konsep Dan Kecerdasan Ganda Siswa Terhadap Hasil Belajar Biologi. Tesis Tidak Diterbitkan), Medan: PPs UNIMED.

Dick \& Carey, (2005), The Systematic Design of Instruction, Boston: Allyn And Bacon.

Djamrah, Sayiful Bahri dan Aswan Zain. 2010. Strategi Belajar Mengajar. Jakarta: Rineka Cipta.

Gardner, Howard. (1983). Frames Of Mind: The Theory of Multiple Intelligences, tenth-anniversary edition, New York: Basic Books.

Gardner, Howard. (1993). Multiple Intelligences: The Theory in Practice. New York: Basic Books.

Gardner, Howard. (2000). Intellegence Reframed: Multiple Intelligences for the $21^{\text {st }}$ Century. New York: Basic Books.

Gunawan, Adi. (2003). Genius Learning Strategy, Jakarta: Gramedia Pustaka Utara.

Hamid, K. Abdul. (2009). Teori Belajar dan Pembelajaran. Medan.

Ibrahim, Muslimin, dkk. (2000). Pembelajaran Kooperatif. Universitas Negeri Surabaya: University Press.

Isjoni. (2009). Pembelajaran Kooperatif. Yogyakarta: Pustaka Pelajar.

Lazear, David. (2000). Pathways of Learning Teaching Students and Parents About Multiple Intelligences, Arizona, Tucson: Zephyr Press.

Lie, Anita. (2002). Cooperative Learning. Jakarta: Grasindo.

Miarso, Yusuf Hadi. (2007). Menyemai Benih Teknologi Pendidikan. Jakarta: Kencana Prenada Media Group.

Miarso, Yusuf Hadi. (2009). Menyemai Benih Teknologi Pendidikan. Jakarta: Kencana Prenada Media Group.

Nasution, S. (2009). Kurikulum dan Pengajaran, Bandung: Bumi Aksara.

Nur, Muhammad. (2005). Pembelajaran Kooperatif. Surabaya: Pusat Sains dan Matematika Sekolah UNESA.

Safaria, T. (2005). Interpersonal Intelligence: Metode Pengembangan Kecerdasan Interpersonal Anak. Yogyakarta: Amara Books.

Sanjaya, Wina. (2010). Strategi Pembelajaran Berorientasi Standar Proses Pendidikan. Jakarta: Prenada Media Group. 
Semiawan, Conny, R. (2004). Perkembangan Anak Usia Dini, Makalah disampaikan pada Seminar dan Lokakarya Nasional Pendidikan Anak Usia Dini, Kerjasama Dirjen PLSP Depdiknas dengan UNJ, Jakarta, 9 - 11 Oktober 2004.

Slavin, Robert dan Masri Kuadrat E. (2008). Cooperative Learning: Theory, Research and Praktice.

Solihatin, Etin dan Raharjo. (2009). Cooperative Learning Jakarta: Bumi Aksara.

Suarca, Kadek., Soetjiningsih, dan IGA. Endah Ardjana. 2005. Kecerdasan Majemuk Pada Anak. Sari Pediatri, Vol. 7, No. 2, September 2005: 85-92.
Sujiono, Yuliani Nurani dan Bambang Sujiono. (2010). Bermain Kreatif Berbasis Kecerdasan Jamak. Jakarta: Indeks.

Suwarna, Al Muchtar. (2009). Strategi Pembelajaran Pendidikan IPS, Bandung: Sekolah Pascasarjana Universitas Pendidikan Indonesia.

Trianto. (2011). Mendesain Model Pembelajaran Inovatif-Progresif. Jakarta: Kencana Prenada Media Group.

Tukimun. (2006). Pengaruh Pembelajaran Konstruktivisme Melalui Penerapan Pembelajaran Kelompok Balik dan Kemampuan Berpikir Matematis Terhadap Hasil Belajar Fisika Siswa Kelas X SMA Negeri I Binjai. Tesis Tidak Diterbitkan. Medan: PPs UNIMED. 